\title{
Aplikasi Karbon Ampas Teh Tersulfonasi Sebagai Katalis Dalam Produksi Biodiesel Dari Pfad (Palm Fatty Acid Destilate)
}

\author{
Isva Abdul Ghani ${ }^{1}$, Muhammad Hiknul Ikhsan ${ }^{1}$, Umar Kalmar Nizar ${ }^{1^{\star}}$, \\ Indang Dewata ${ }^{1}$, Ali Amran ${ }^{1}$, Suryelita ${ }^{1}$, Hary Sanjaya ${ }^{1}$ \\ De Program StudiKimia, Fakultas Matematika dan IImu Pengetahuan Alam, Universitas Negeri Padang,Indonesia \\ `E-mail: umarkn@fmipa.unp.ac.id
}

\section{ABSTRACT}

In this study, a solid acid catalyst based on sulfonated tea waste carbon was used in the biodiesel production process. This study aims to synthesize solid acid catalyst, characterize the physicochemical properties of the catalyst, and test the catalytic activity of the catalyst in biodiesel production. The catalyst was synthesized by carbonization process with N2 gas stream and without N2 gas stream at 350C for 1 hour. Then proceed with the sulfonation process using H2SO 4 for 4 hours. The resulting catalyst was characterized using FTIR and the determination of the number of catalyst acid sites. FTIR data of catalyst samples with sulfonated N2 gas stream (SCCS-N2) and carbon samples without sulfonated N2 gas stream (SCCS-TN2) showed a strong transmittance peak observed at wave number $1190 \mathrm{~cm}-1$ and $1060 \mathrm{~cm}-1$ which indicate the presence of symmetrical and asymmetrical vibrations of the $O=S=O$ group. In determining the number of acid sites on the catalyst obtained the number of acid sites on the catalystSCCS-N2 is $700 \mathrm{~mol} / \mathrm{g}$ and the number of acid sites for SCCS-TN2 is $600 \mathrm{~mol} / \mathrm{g}$. In the catalyst catalytic activity test, the density of biodiesel produced was $0.8434-0.8714 \mathrm{~g} / \mathrm{ml}$ and the highest conversion percentage was found in biodiesel from SCCS-N2 catalyst, which was $25.4523 \%$.

Keywords : Catalyst With N2 Gas Flow, Catalyst Without N2 Gas Flow, Physicochemical Properties of Catalyst, Catalytic Activity, Biodiesel

\begin{abstract}
ABSTRAK
Pada penelitian ini digunakan katalis asam padat berbasis karbon ampas teh tersulfonasi dalam proses produksi biodiesel. Penelitian ini bertujuan untuk mensintesis katalis asam padat, mengkarakterisasi sifat fisikokimia katalis, dan menguji aktivitas katalitik katalis dalam produksi biodiesel. Katalis disintesis melalui proses karbonisasi dengan aliran gas $\mathrm{N}_{2}$ dan tanpa aliran gas $\mathrm{N}_{2}$ pada suhu $350^{\circ} \mathrm{C}$ selama $1 \mathrm{jam}$. Kemudian dilanjutkan dengan proses sulfonasi mengunakan $\mathrm{H}_{2} \mathrm{SO}_{4}$ selama $4 \mathrm{jam}$. Katalis yang dihasilkan dikarakterisasi mengunakan FTIR dan penentuan jumlah situs asam katalis. Data FTIR sampel katalis dengan aliran gas $\mathrm{N}_{2}$ tersulfonasi (SCCS- $\mathrm{N}_{2}$ ) dan sampel karbon tanpa aliran gas $\mathrm{N}_{2}$ tersulfonasi $\left(\mathrm{SCCS}-\mathrm{TN}_{2}\right.$ ) menunjukkan puncak transmittan yang kuat yang diamati pada bilangan gelombang $1190 \mathrm{~cm}^{-1}$ dan $1060 \mathrm{~cm}^{-1}$ yang mengindikasi adanya vibrasi simetris dan asimetris dari gugus $\mathrm{O}=\mathrm{S}=\mathrm{O}$. Pada penentuan jumlah situs asam katalis didapatkan jumlah situs asam pada katalis SCCS $-N_{2}$ yaitu $700 \mu \mathrm{mol} / \mathrm{g}$ dan jumlah situs asam katalis SCCS-TN 2 yaitu $600 \mu \mathrm{mol} / \mathrm{g}$. Pada uji aktivitas katalitik katalis didapatkan densitas biodiesel yang dihasilkan yaitu $0,8434-0,8714 \mathrm{~g} / \mathrm{ml}$ dan persen konversi tertinggi terdapat pada biodiesel dari katalis SCCS- $\mathrm{N}_{2}$ yaitu $25,4523 \%$
\end{abstract}

Kata Kunci : Katalis Dengan Aliran Gas $\mathbf{N}_{2}$, Katalis Tanpa Aliran Gas $\mathbf{N}_{2}$, Sifat Fisikokimia Katalis, Aktivitas Katalitik, Biodiesel

\section{PENDAHULUAN}

Biodiesel meruapakan salah satu bahan bakar alternatif yang dikembangkan untuk mengatasi berkurangnya sumber bahan bakar fosil. Bahan bakar ini dihasilkan dari reaksi transesterifikasi trigliserida dengan alkohol atau asam lemak bebas dengan alkohol. Sebagai bahan bakar alternatif pengganti diesel, biodiesel sangat menjanjikan dikembangkan di Indonesia. Hal ini disebabkan bahan baku (feedstock) dan katalis yang digunakan untuk produksi biodiesel dapat disintesis menggunakan limbah organik dari kearifan lokal Indonesia.

Limbah untuk produksi biodiesel dapat diperoleh dari minyak sisa penggorengan ( waste cooking oil = WCO) atau distilat asam lemak sawit (palm fatty acid distillated = PFAD). Waste cooking lebih mudah diperoleh karena dihasilkan dari limbah penggorengan rumah tangga, restoran dan penjual jajaranan gorengan. Namun demikian penggunaan WCO sebagai bahan baku biodiesel dilaporkan perlu pretreatment seperti penyaringan dan suhu reaksi relatif tinggi jika digunakan katalis asam. PFAD merupakan produk samping dari pengolahan minyak sawit mentah yang mengandung $85 \%$ FFA, sehingga dapat digunakan menggunakan katalis asam dengan suhu sekitar titik didih alkohol.

Katalis memegang peranan penting dalam produksi biodiesel. Penggunaan katalis untuk produksi biodiesel tergantung dari feedstock yang digunakan. Untuk mengkonversi PFAD menjadi biodiesel, katalis yang sesuai adalah katalis asam padat berbasis karbon tersulfonasi. Katalis disintesi melalui karbonisasi limbah organik dan dilanjutkan dengan proses sulfonasi. Proses karbonisasi dapat dilakukan dengan kalsinasi dengan adanya oksigen dan tanpa oksigen (dengan mengalirkan gas $\mathrm{N}_{2}$ ). Sejumlah limbah seperti tandan sawit, kulit biji sawit, bambu, ampas tebu dan bonggol jagung telah dilaporkan sebagai sumber karbon dalam sintesis katalis karbon tersulfonasi. 
Ampas teh merupakan salah satu limbah organik yang dihasilkan dari industri minuman. Ampas teh mengandung sellulosa sebanyak $34 \%$ dan tanin sebanyak $22 \%$. Berdasarkan komposisinya, ampas teh sangat potensial sebagai sumber karbon alternatif untuk katalis katalis karbon tersulfonasi karena memiliki kandungan sellulosa dan tanin yang cukup tinggi (Güler et al, 2017). Oleh karena itu dalam penelitian ini dilaporkan perbandingan metoda karbonisasi ampas teh dengan adanya oksigen dan tanpa oksigen (dengan mengalirkan gas $\mathrm{N}_{2}$ ). Karbon yang dihasilkan disulfonasi dengan asam sulfat dan aplikasikan untuk produksi biodiesel dari PDAF. Pada penelitian ini dilaporkan perbandingan metoda kalsinasi dengan dan tanpa oksigen pada sintesis katalis karbon ampas teh tersulfonasi yang nantinya diaplikasikan pada produksi biodiesel menggunakan PFAD.

\section{METODE}

Bahan-bahan yang dibutuhkan dibagi tiga yaitu bahan sintesis katalis, bahan pembuatan biodiesel, dan bahan untuk pengujian PFAD dan biodiesel.Bahan untuk pembuatan katalis yaitu ampas teh, asam sulfat, akuades, dan n-heksana.Bahan untuk pembuatan biodiesel yaitu PFAD, metanol, dan katalis. Bahan untuk pengujian PFAD dan biodiesel yaitu $\mathrm{KOH}, \mathrm{HCl}$, etanol, $\mathrm{NaCl} 1 \mathrm{M}, \mathrm{NaOH} 0,1 \mathrm{M}$ dan indikator pp. Peralatan yang digunakan dalam penelitian ini terdiri dari peralatan gelas untuk preparasi katalis dan produksi biodiesel serta FTIR untuk karakterisasi katalis.

Sintesis Katalis Asam Padat Berbasis Karbon Ampas Teh Tersulfonasi dilakukan dengan cara mengeringkan sampel diudara terbuka seminggu dan dioven selama 24 jam pada suhu $105^{\circ} \mathrm{C}$. Sampel yang sudah kering dikalsinasi dengan gas $\mathrm{N}_{2}$ dan tanpa gas $\mathrm{N}_{2}$ pada suhu $350^{\circ} \mathrm{C}$ selama 1 jam. Sampel hasil kalsinasi selanjutnya dihaluskan dan disimpan dalam desikator (Farabi et al., 2019).Karbon hasil kalsinasi yang telah dihaluskan sebanyak 5 gram direfluks dalam $200 \mathrm{ml}$ asam sulfat pekat dengan waktu 4 jam dan suhu $160^{\circ} \mathrm{C}$. Produk yang dihasilkan dikarakterisasi dengan FTIR serta diaplikasikan pada pembuatan biodiesel. Katalis asam padat yang dihasilkan melalui proses kalsinasi dan sulfonasi dinamakan SCCS- $\mathrm{N}_{2}$ (Katalis dengan aliran gas $\mathrm{N}_{2}$ ) dan SCCS- $\mathrm{TN}_{2}$ (Katalis tanpa aliran gas $\mathrm{N}_{2}$ ).

Karakterisasi katalis menggunakan FTIR dilakukan dalam fase padat berbentuk bubuk yang telah dikeringkan.Katalis di karakterisasi pada bilangan gelombang 400-4000 $\mathrm{cm}^{-1}$. Karakterisasi ini bertujuan untuk menentukan gugus fungsi dan jenis ikatan yang terdapat dalam sampel. Sampel yang dikarakterisasi adalah karbon hasil kalsinasi dan karbon tersulfonasi (Farabi et al.2019).

Penentuan jumlah situs asam katalis asam padat berbasis karbon ampas teh tersulfonasi digunakan metode titrasi acidimetri. Pada titrasi acidimetri ini sampel ditimbang 1 gram kedalam erlemyer dengan menggunakan neraca analitik, selanjutnya ditambahakan $50 \mathrm{ml}$ larutan $\mathrm{NaCl} 1 \mathrm{M}$, kemudia dishakker pada kecepatan 130rpm selama 4jam, selanjutnya disaring dengan kertas saring whapman 42 . Filtrat selanjutnya dititrasi dengan larutan $\mathrm{NaOH}$ 0,1 M dengan mengguankan indikator PP.

Pembuatan biodiesel dilakukan melalui reaksi esterifikasi antara PFAD dengan metanol dengan penambahan katalis asam padat kedalam reaksi.Reaksi berlangsung pada labu leher tiga dengan sistem refluks yang dilengkapi termometer.Reaksi esterifikasi berlangsung pada suhu $65^{\circ} \mathrm{C}$ dengan waktu reaksi selama 2 jam. Pada proses esterifikasi perbandingan mol metanol dengan PFAD yaitu 6:1 dan jumlah katalis yang digunakan yaitu $4 \% w / t$ dari berat PFAD.

Campuran kemudian didinginkan setelah reaksi berlangsung. Selanjutnya dilakukan proses pemisahan antara produk dengan katalis menggunakn sentrifus. Pada pemisahahan tersebut gliserol yang terbentuk akan terpisah dari campuran karena memiliki fase yang sama dengan katalis. Pemisahan selanjutnya dilakukan terhadap kelebihan metanol deng cara pemanasan pada suhu $65^{\circ} \mathrm{C}$ diatas hotplate.

Katalis yang telah dipisahkan dari biodiesel selanjutnya di recycel dengan menggunakan metode sonikasi agar dapat digunakan kembali.Katalis disonikasi dengan menggunakan $\mathrm{N}$-heksan dengan alat ultrasonik untuk menghilangkan gliserol dan PFAD yang menenmpel pada katalis. Katalis yang telah bebas dari gliserol dan PFAD dibilas menggunakan metanol untuk memurnikan katalis dari $\mathrm{N}$-heksan dan kemudian dipisahkan dan dikeringkan.Katalis yang sudah dikeringkan dapat digunakan kembali untuk pembuatan biodiesel tahap selanjutnya.

Penentuan bilangan asam pada sampel PFAD dan produk biodiesel bertujuan untuk menentukan jumlah asam lemak bebas.Sampel ditimbang 3-5 gram kedalam erlemeyer ditambahkan 30-50 ml pelarut yang telah dinetralkan dan diaduk sampai homogen sebagai pelarut. Penetralan dilakukan dengan penambahan $\mathrm{KOH} 0,05$ $\mathrm{N}$ dengan menggunakan indikator pp. Sampel selanjutnya ditambahklan beberapa tetes indikator pp.Apabila sampel tidak larur, tempatkan campuran diatas hotplate, atur suhu pada $40^{\circ} \mathrm{C}$ kemudian duaduk sampel pelanpelan sambil dititrasi dengan larutan $\mathrm{KOH} 0,05 \mathrm{~N}$. Titrasi akhir titrasi bila warna campuran saat berubah menjadi pink permanen selama 30 detik sambil terus diaduk agar homogen.

Rumus :

$$
\text { Bilangan Asam }=\frac{(\mathrm{V} . \mathrm{N}) \mathrm{KOH} \times \mathrm{BM} \mathrm{KOH}}{\text { Berat Sampel }(\text { gram })}
$$

Pengujian densitas pada biodiesel bertujuan untuk melihat massa jenis biodiesel yang dihasilkan dengan massa jenis standar biodiesel yang telah ditetapkan. Sampel ditimbang dengan piknometer dengan menggunakan neraca analitik kemudian dikurang dengan berat piknometer kosong. Berat biodiesel dibagi dengan volume piknometer. 
Rumus :

Densitas $=\frac{\mathrm{W} 2-\mathrm{W} 1}{\mathrm{~V}(\mathrm{ml})}$

W1 $=$ Berat piknometer kosong

W2 $=$ Berat piknometer + sampel

$\mathrm{V}=$ Volume piknometer

Penentuan bilangan asam padas biodiesel bertujuan menentukan jumlah asam lemak bebas dari produk yang dihasilkan.Sampel biodiesel ditimbang 500mg kedalam erlemeyer ditambahkan 50ml etanol.Kemudian distirer dan dipanaskan selama 30 menit.Selanjutnya dititrasi dengan larutan $\mathrm{KOH}$ dalam etanol 0,5N.Dicatat volume $\mathrm{KOH}$ dalamn etanol yang digunakan sampai titik ekivalen.Berdasarkan nilai bilangan asam dari PFAD dari biodiesel yang dihasilkan dapat ditentukan persen konversi.

Rumus:

$$
\begin{aligned}
\text { Bilangan Asam }= & \frac{(\mathrm{V} . \mathrm{N}) \mathrm{KOH} \times \mathrm{BM} \mathrm{KOH}}{\text { Berat Sampel }(\text { gram })} \\
\% \text { Konversi } & =\frac{\text { Bilangan Asam PFAD - Bilangan Asam Biodiesel }}{\text { Bilangan Asam PFAD }} \times 100 \%
\end{aligned}
$$

\section{HASIL DAN PEMBAHASAN}

\section{FTIR Spectra Of Sulfonated Tea Waste Carbon}

Sampel karbon ampas teh dan katalis karbon ampas teh tersulfonasi dianalisis dengan menggunakan FTIR pada bilangan gelombang $4000-600 \mathrm{~cm}^{-1}$. Keberadaan gugus fungsi pada karbon ampas teh dan karbon ampas teh tersulfonasi dapat dilihat pada gambar 1. Berdasarkan gambar 1, spektra karbon hasil kalsinasi dan hasil sulfonasi menunjukan pita serapan utama pada bilangan gelombang sekitar $1700-1680 \mathrm{~cm}^{-1}, 1650-1550 \mathrm{~cm}^{-}$ $1,1190-1030 \mathrm{~cm}^{-1}$.

Spektrum IR menunjukkan adsorpsi yang lemah disekitar $1690 \mathrm{~cm}^{-1}$ pada SCCS- $\mathrm{TN}_{2}$ dan SCCS- $\mathrm{N}_{2}$ yang menandakan adanya gugus $\mathrm{OH}$ yang berasal dari gugus sulfonat $\left(\mathrm{SO}_{3} \mathrm{H}\right)$. Situs ini memiliki peranan penting dalam proses esterifikasi yang secara tidak langsung meningkatkan aktifitas katalitik dari katalis. Selain itu, adsorpsi kuat disekitar daerah $1600 \mathrm{~cm}^{-1}$ yang menandakan adanya cincin aromatik $\mathrm{C}=\mathrm{C}$ pada $\mathrm{CCS}-\mathrm{TN}_{2}, \mathrm{CCS}-$ $\mathrm{N}_{2}$, SCCS-TN 2 , dan SCCS- $\mathrm{N}_{2}$. Pada pita serapan disekitar $1050 \mathrm{~cm}^{-1}$ menunjukkan ikatan C-O dari gugus C-O-H pada tannin dan C-O-C dari ikatan glikosida dalam sellulosa. Selain itu, puncak transmitan kuat diamati sekitar $1190 \mathrm{~cm}^{-1}$ dan $1060 \mathrm{~cm}^{-1}$ pada katalis karbon ampas teh tersulfonasi yang masing-masing menandakan terdapatnya gugus $\mathrm{O}=\mathrm{S}=\mathrm{O}$ simetris dan asimetris yang berasal dari gugus sulfonat $\left(\mathrm{SO}_{3} \mathrm{H}\right)$.

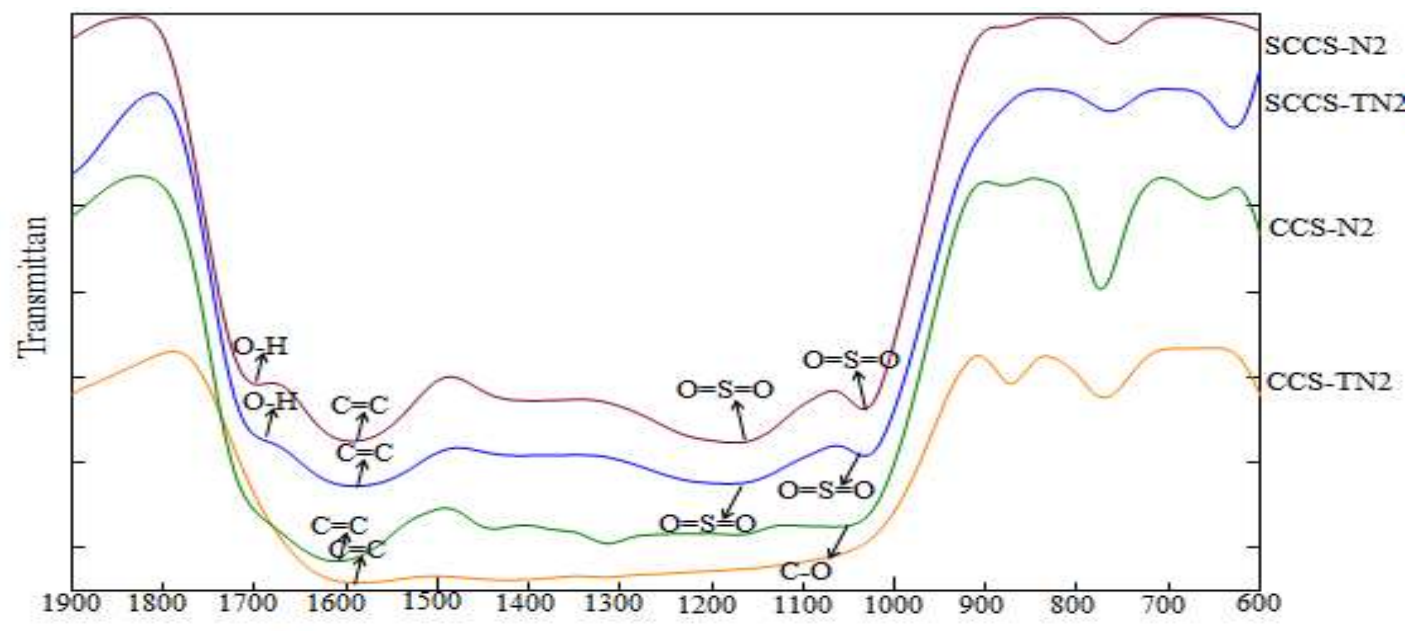

Gambar 1. Bilangan Gelombang Spektra FTIR Karbon Ampas Teh dan Katalis Karbon Ampas Teh Tersulfonasi.

\section{Acid cites of catalysts}

Jumlah situs asam katalis ditentukan mengunakan metode titrasi acidimetri.Acidimetri merupakan metode volumetri yang digunakan untuk menentukan konsentrasi analit yang bersifat asam. Metode ini sangat cocok digunakan untuk menentukan jumlah situs asam $\left(\mathrm{SO}_{3} \mathrm{H}\right)$ pada katalis.Pada metode ini larutan standar yang digunakan untuk penetuan jumlah situs asam adalah larutan $\mathrm{NaOH}$. 


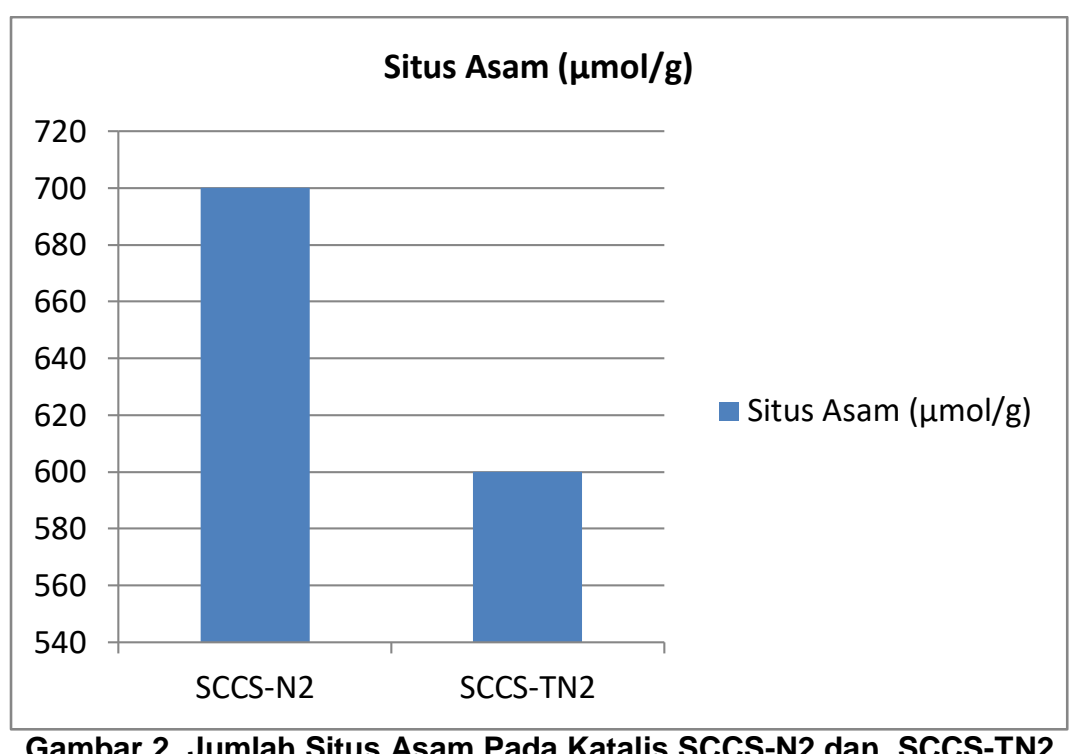

Gambar 2 menunjukkan jumlah situs asam pada ktalis SCCS- $\mathrm{N}_{2}$ dan SCCS-TN 2 . Pada katalis SCCS-N $\mathrm{S}_{2}$ terdapat jumlah situs asam $700 \mu \mathrm{mol} / \mathrm{g}$ sedangkan pada katalis SCCS-TN $\mathrm{T}_{2}$ terdapat jumlah situs asam 600 $\mu \mathrm{mol} / \mathrm{g}$. Kandungan situs asam yang lebih tinggi pada katalis SCCS- $\mathrm{N}_{2}$ dibandingkan katalis SCCS-TN $\mathrm{S}_{2}$ dapat mempengaruhi aktifiktas katalitik katalis. Katalis yang memiliki jumlah situs asam terbanyak dapat optimum pada saat reaksi pembutan biodiesel dikarenakan jumlah asam yang banyak akan membantu reaksi kesetimbangan kearah produk sehingga dihasilkan konversi biodiesel yang lebih tinggi.

\subsection{Analisis Sifat-Sifat Biodiesel}

\section{A. Densitas}

Densitas merupakan aspek penting pada bahan bakar. Densitas bahan bakar mempengaruhi massa bahan bakar yang diinjeksikan ke ruang pembakaran. Dengan demikian, perubahan densitas bahan bakar akan mmepengaruhi daya output mesin karena massa bahan bakar yang diinjeksikan berberda. Standar densitas negara-negara Eropa berada di kisaran $860-900 \mathrm{~kg} / \mathrm{m}^{3}$.

Densitas biodiesel yang dihasilkan dengan menggunakan katalis karbon tersulfonasi ditentukan dengan menggunakan piknometer. Data hasil uji densitas dapat dilihat pada gambar 3.

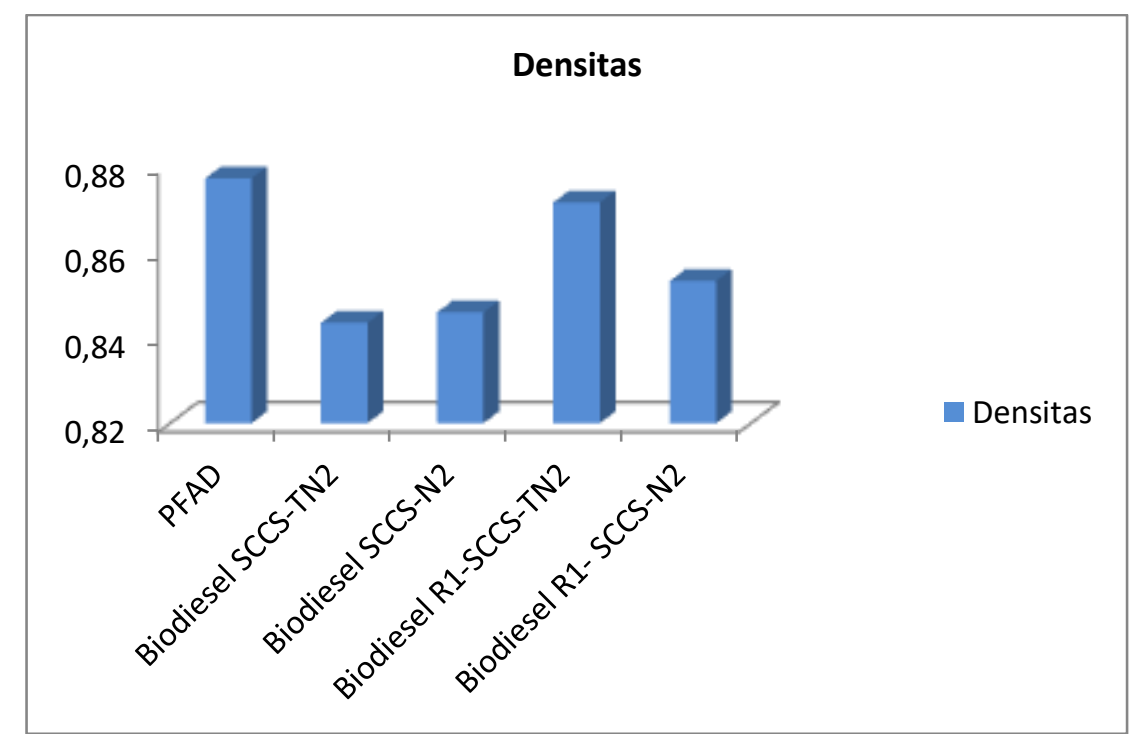

Gambar 3. Hasil Uji Densitas 
Berdasarkan analisis yang telah dilakukan diperoleh densitas biodiesel yang lebih rendah daripada PFAD. Penurunan densitas tersebut menunjukan adanya aktivitas katalitik dari katalis. Penurunan densitas yang

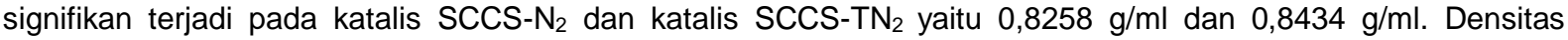
kemudian mengalami peningkatan pada penggunaan katalis hasil receyle $R_{1}$ SCCS- $N_{2}$ dan $R_{1}$-SCCS-TN $N_{2}$ yaitu $0,8531 \mathrm{~g} / \mathrm{ml}$ dan $0,8714 \mathrm{~g} / \mathrm{ml}$. Densitas biodiesel yang didapatkan pada katalis receyle sesuai dengan standar densitas negara-negara Eropa 0,8600 g/ml- 0,9000 g/ml

\section{Bilangan Asam dan Persentase Konversi}

Penentuan bilangan asam bertujuan untuk menentukan jumlah kandungan asam pada produk biodiesel. Kandungan asam yang tinggi pada biodiesel dapat menyebabkan masalah korosi pada mesin pada saat penggunaan bahan bakar tersebut. Bilangan asam pada biodiesel dijadikan indikator untuk menentukan tingkat keberhasilan dalam pembuatan biodiesel. Bilangan asam yang lebih rendah daripada bahan baku menunjukkan indikator koversi asam lemak menjadi asam lemak metil ester yang tinggi. Data hasil uji bilangan asam dan persentase konversi dapat dilihat pada gambar 4 dan gambar 5.

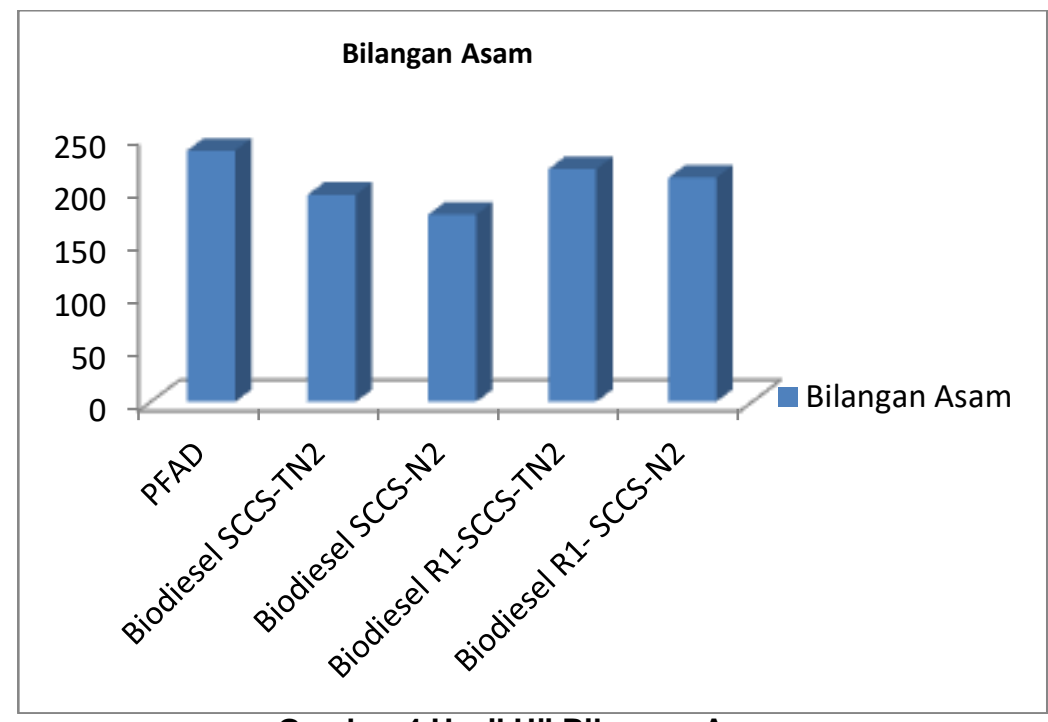

Gambar 4 Hasil Uji Bilangan Asam

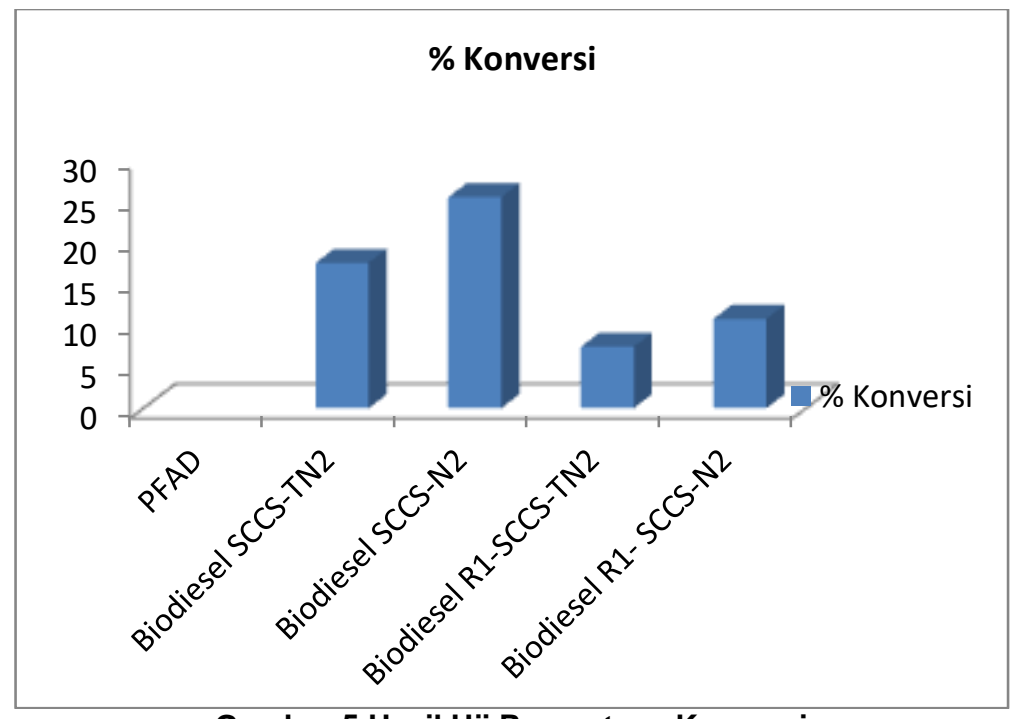

Gambar 5 Hasil Uji Persentase Konversi

Pada tabel 2 bilangan asam biodiesel mengalami penurunan yang cukup signifikan pada penggunaan katalis SCCS-TN 2 dan SCCS-N 2 yaitu $195,0182 \mathrm{mg} / \mathrm{KOH}$ dan $176,3178 \mathrm{mg} / \mathrm{KOH}$. Penurunan yang cukup signifikan ini mengindikasi bahwa terjadi aktivitas katalitik yang cukup baik pada reaksi produksi biodiesel. Selanjutnya penggunaan katalis hasil receycleR ${ }_{1}$ SCCS- $\mathrm{N}_{2}$ dan $\mathrm{R}_{1}$-SCCS-TN $\mathrm{N}_{2}$ tidak menurunkan bilangan asam secara signifikan. Hal ini disebabkan terjadinya penurunan aktifitas katalitik katalis didalam reaksi produksi biodiesel. Penurunan aktifitas katalistik tersebut disebabkan oleh kurang reaktifnya katalis yang disebakan tersumbatnya pori katalis oleh zat perantara seperti asam lemak yang tidak ikut bereaksi. Disamping itu, 
penurunan jumlah gugus $\left(\mathrm{SO}_{3} \mathrm{H}\right)$ yang tidak kembali ke katalis pada akhir proses esterifikasi menjadi penyebab utama penurunan aktivitas katalitik.

Berdasarkan pemaparan hasil uji sifat biodiesel yang dihasilkan menunjukkan bahwa produk biodiesel dengan menggunakan katalis SCCS- $\mathrm{N}_{2}$ memberikan hasil yang cukup baik. Hal ini dibuktikan dengan persentase konversi yang cukup tinggi dibandingkan dari katalis SCCS-TN 2 .

\section{KESIMPULAN}

Katalis karbon ampas teh tersulfonasi dapat disintesis dengan menggunakan metode kalsinasii aliran gas $\mathrm{N}_{2}$ dan tanpa aliran gas $\mathrm{N}_{2}$ dan kemudian disulfonasi dengan menggunakan $\mathrm{H}_{2} \mathrm{SO}_{4}$

Sifat- sifat fisikokimia katalis asam padat berbasis karbon ampas teh tersulfonasi dikaraketrisasi dengan menggunakan FTIR mempunyai pita serapan yang kuat pada bilangan gelombang $1190 \mathrm{~cm}^{-1}$ dan $1060 \mathrm{~cm}^{-1}$. Pada analisis jumlah situs asam dengan menggunakan metode titrasi acidimetri didapatkan jumlah situs asam pada katalis SCCS-N $\mathrm{N}_{2}$ yaitu $700 \mu \mathrm{mol} / \mathrm{g}$ dan pada katalis SCCS $\mathrm{TN}_{2}$ yaitu $600 \mu \mathrm{mol} / \mathrm{g}$.

Sifat-sifat biodiesel yang dihasilkan dari katalis karbon ampas teh tersulfonasi didapatkan densitas biodiesel mengalami penurunan yang cukup signifikan dibandingkan PFAD dan didapatkan persentase konversi tertinggi pada katalis SCCS- $\mathrm{N}_{2}$ yaitu $25,4523 \%$

Reusability katalis karbon ampas teh tersulfonasi mengalami penurunan aktivitas katalitik yang dibuktikan dengan didapatkan densitas biodiesel yang tidak mengalami penurunan signifikan dibandingkan PFAD dan didapatkan persentase konversi terendah pada katalis $\mathrm{R}_{1}$-SCCS- $\mathrm{TN}_{2}$ yaitu 7,3800\%

\section{UCAPAN TERIMA KASIH}

Penulis mengucapkan terima kasih kepada Direktorat Penelitian dan Pengabdian Universitas Negeri Padang, atas bantuan dana penelitiannya dan juga untuk Laboratorium Kimia, Fakultas Matematika dan IImu Pengetahuan Alam, Universitas Negeri Padang atas sarana dan dukungannya.

\section{REFERENSI}

1. Akinfalabi, S. I., Rashid, U., Yunus, R., \& Taufiq-Yap, Y. H. (2017). Synthesis of biodiesel from palm fatty acid distillate using sulfonated palm seed cake catalyst.RenewableEnergy, 111(17),611619.https://doi.org/10.1016/j.renene .2017.04.056

2. Fadhil, A. B., Dheyab, M. M., \& Abdul-Qader, A. Q. Y. (2012). Purification of biodiesel using activated carbons produced from spent tea waste. Journal of the Association of Arab Universities for Basic and Applied Sciences, 11(1), 45-49. https://doi.org/10.1016/j.jaubas.2011.12.001

3. Farabi, M. S. A., Ibrahim, M. L., Rashid, U., \& Taufiq-Yap, Y. H. (2019). Esterification of palm fatty acid distillate using sulfonated carbon-based catalyst derived from palm kernel shell and bamboo. Energy Conversion and Management,181(December2018),562-570.https://doi.org/10.1016/j.encon- man 2018.12.033

4. Güler, Ö., Boyrazlı, M., Başgöz, Ö., \& Bostancı, B. (2017). The synthesis of carbon nanostructures from tea plant wastes. Canadian Metallurgical Quarterly, 56(3), https://doi.org/10.1080/00084433.2017.1345467

5. Lokman, I. M., Rashid, U., \& Taufiq-Yap, Y. H. (2016). Meso- and macroporous sulfonated starch solid acid catalyst for esterification of palm fatty acid distillate.ArabianJournalofChemistry,9(2), 179189.https://doi.org/10.1016/j.arabjc.2015.06.034

6. Wang, Y. T., Yang, X. X., Xu, J., Wang, H. L., Wang, Z. B., Zhang, L., ... Liang, J. L. (2019). Biodiesel production from esterification of oleic acid by a sulfonated magnetic solid acid catalyst. Renewable Energy, 139, 688-695. https://doi.org/10.1016/j.renene.2019.02.111

7. Wong, S., Lee, Y., Ngadi, N., Inuwa, I. M., \& Mohamed, N. B. (2018). Synthesis of activated carbon from spent tea leaves for aspirin removal. Chinese Journal of Chemical Engineering, 26(5), 1003-1011. https://doi.org/10.1016/j.cjche.2017.11.004 